\section{A Monograph on Veins}

By Kenneth J. Franklin. Pp. xxii +410. London : Baillière, Tindall and Cox, 1937.) $27 s$.

T $F$ anyone supposes that little is known about veins 1 his opinion will be altered when he reads this scholarly, but interesting, monograph, which covers the whole literature from the sixth century B.c. to 1936 from the points of view of the anatomist, embryologist, pharmacologist, histologist, clinician, historian and photographer-in fact from the point of view of the physiologist.

Veins have been Dr. Franklin's principal interest since 1924 and he has published many papers describing skilful work carried out with careful accuracy. Fleisch and Gollwitzer-Meier have simultaneously concentrated on the same problem. Few people have known enough about veins to appreciate the significance of this work, but Dr. Franklin has now fitted the pieces together. He was himself surprised at how well they fitted and many of his readers will share his emotion. It must not be imagined, however, that the picture is complete, for many fundamental problems are still a matter of controversy. For example, John Hunter suggested that the pulsations in arteries acted on veins like the movements of a piston in a pump, forcing the blood past the valves. This theory has been accepted by some and rejected by others, but the propulsive effect has never been demonstrated, though compression of veins by the pulse has been observed by $\mathbf{X}$-rays in men and dogs.

The subjects discussed include the blood depots, the peculiar vascular anatomy of diving animals, the effects of muscular contraction and respiration on the venous return, the pharmacological and nervous control of veins, venous pressure, arterio-venous anastomoses, varicose veins and the history of intravenous injections and venesection.

The book is attractively produced with excellent photographs, diagrams and historical portraits. About 1,200 references are given in the bibliography.

J. H. G.

The Annual Register :

a Review of Public Events at Home and Abroad for the Year 1937. New Series. Edited by Dr. M. Epstein. Pp. xiv +488 . (London : Longmans, Green and Co., Ltd., 1938.) 30s. net.

\ITH unfailing punctuality this concise review of world history and achievement makes its appearance. A calm review of the stormy year of 1937 can have been no easy task, but it has been achieved without bias yet with enough spirit and vivacity to make it readable from beginning to end. As usual, British and foreign history each occupy about one third of the book. Particular praise may be given to the survey of internal affairs in Great Britain and to the accounts of Germany and the Soviet Union. Spain, China, Japan and the United States also occupy many pages. The writer of the survey of the literature of the year comments on the deterioration in standards of human justice and the discouragement of free speech which he believes have tended to slacken creative effort. Unfortunately it is impossible to deny this belief. The survey of science, however, records advances in several directions although the condensation of the account, no doubt on the grounds of space, is almost excessive. There are also the usual surveys of art, drama, law and finance. Among the public documents printed in full are the Constitution of Ireland and the United States Neutrality Act. The obituaries of the year give admirable biographies of eminent men and women of all countries.

\section{Théorie Cinétique des Liquids}

1. Fluctuations en Densité. 2. La propagation et la Diffusion de la Lumière. Par Prof. J. Yvon. (Actualités scientifique et industrielles, Nos. 542 and 543.) Pp. 133, together. 18 francs each.

$7 \mathrm{HE}$ author develops a theory of the propagation 1 and diffusion of plane polarized light without change of wave-length by a monatomic liquid, for example, argon, the molecules of which are assumed to be spherical and isotropic. The first part deals with the density distribution and the effect on it of gravity and thermal agitation, the second with the dielectric constant, refractive index and diffusion of such a liquid, the statistical method of Gibbs being used throughout. An expression for the ratio of the strength of the source of diffused light furnished by a volume of the liquid per unit intensity of the incident light (Rayleigh's ratio) is obtained which agrees satisfactorily with experimental results for benzene but not for water. As neither is monatomic, observations on monatomic liquids are required before attempts are made to extend the theory to complex molecules. Each part contains nearly 100 references.

\section{The Statesman's Year-Book :}

Statistical and Historical Annual of the States of the World for the Year 1938. Edited by Dr. M. Epstein. Seventy-fifth Annual Publication, revised after Official Returns. Pp. xxvi + 1497. (London: Macmillan and Co., Ltd., 1938.) 20s. net.

7 HIS annual has effected a significant change this year. The first part of the book is no longer entitled "The British Empire" but has become "The British Commonwealth of Nations". Within this embracing title comes first of all the British Empire, including Great Britain and Northern Ireland, the Colonies, Protectorates, India and Burma, and secondly the Dominions, concluding with Ireland. The remaining sections of the book have undergone no change in arrangement but the usual careful revision in detail. Abyssinia and Austria linger in their alphabetical places, but all effective and other changes in their Governments are noted. The section on the States of Germany has disappeared. As usual, corrections and additions are made up to the end of March or even later. Of the two coloured maps, one illustrates the strategic position of Singapore and the second shows the distribution of steel production and associated ores, iron, manganese chromite, etc., throughout the world. 